\title{
Multimodal imaging of bilateral macular hole in X- linked retinoschisis
}

\author{
Deepika C Parameswarappa, Akash Belenje, Padmaja Kumari Rani
}

Smt. Kanuri Santhamma Centre for Vitreo-Retinal Diseases, LV Prasad Eye Institute, Hyderabad, Telengana, India

\section{Correspondence to Dr Padmaja Kumari Rani; rpk@lvpei.org}

Accepted 24 August 2020

\section{DESCRIPTION}

A 25 -year-old man presented with decreased vision in both eyes over the past 10 years. On examination his best corrected visual acuity was 20/100 and N18 in both eyes. Anterior segment examination was unremarkable. Fundus examination of both eyes was remarkable for full thickness macular hole (figure 1A,B). Fundus autofluorescence (FAF) revealed hypoautofluorescence at the centre of the macula and hyperautofluorescence surrounding it (figure 1C,D). Optical coherence tomography (OCT) showed full thickness macular hole with schitic changes at the level of outer nuclear and inner nuclear layers with loss of outer retinal layers (figure 2A,B). The peripheral examination of the fundus did not reveal any other areas of schisis or degenerative changes. Full field electroretinogram (ERG) showed electronegative pattern of $b$ wave in scotopic bright flash ERG (figure 2C,D). Retrospective evaluation of family history revealed macular hole with retinoschisis in younger brother. Based on positive family history, retinoschisis with macular hole and an electronegative ERG, a diagnosis of $\mathrm{X}$-linked retinoschisis (XLRS) with macular hole was made. The patient was advised to use magnification devices for near vision. Surgical intervention for macular hole was not advised as the vision was stable over the last 5 years and OCT showing loss of outer retinal layers, with FAF showing hypoautofluorescence at the centre which is suggestive of low-visual potential even after surgery.

Juvenile XLRS is a congenitally inherited retinal degenerative condition. ${ }^{1-3}$ It is due to mutation in RS1 gene which codes for protein retinoschisin, responsible for integrity of photoreceptors, bipolar

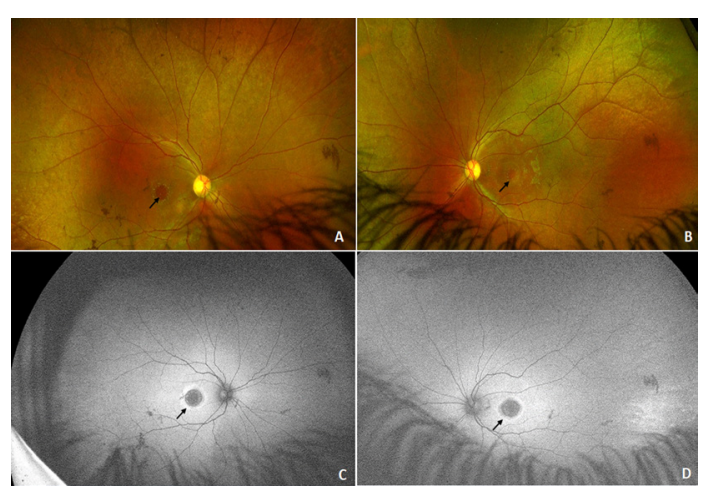

Figure 1 Fundus of both eyes (right eye: $\mathrm{A}$ and left eye: B) showed full thickness macular hole. Fundus autofluorescence of both eyes (right eye: $C$ and left eye: D) showed hypoautofluorescence at the centre of macula and hyperautofluorescence surrounding it.

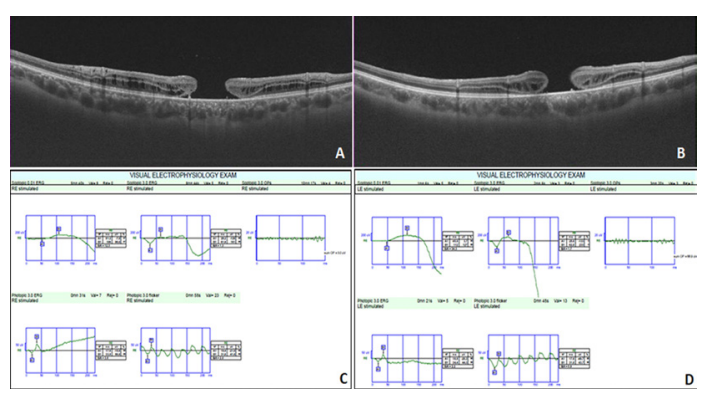

Figure 2 Optical coherence tomography of both eyes (right eye: $A$ and left eye: $B$ ) showed full thickness macular hole with schitic changes at the level of outer nuclear and inner nuclear layers and loss of outer retinal layers. Full field electroretinogram (ERG) showed slight reduction in amplitude of a wave with electronegative pattern of $b$ wave in scotopic bright flash ERG (right eye: C and left eye: D).

cells, and in turn the retinal layers. ${ }^{3-6}$ Men are much more commonly affected with women typically being carriers, however both genders can be affected. ${ }^{12}$ XLRS is usually present at birth but manifests in the first to second decade. Affected men present with moderate visual loss and schisis at various levels of retinal layers. ${ }^{3}$ Foveal schisis is present in almost all patients, however the peripheral schisis is present in only about half of them. ${ }^{1}$ OCT shows characteristic finding of splitting of retinal layers at various levels. ${ }^{78}$ The ERG shows electronegative pattern in which the amplitude of the $\mathrm{b}$ wave is less than that of a wave. ${ }^{89}$

Patient with XLRS can present with complications such as vitreous haemorrhage, retinal detachment and rarely macular holes. ${ }^{130-13}$ Factors found to be responsible for occurrence of macular hole in XLRS are foveal schisis, degenerative cysts, tangential traction, deroofing of the degenerative schitic cysts. ${ }^{10-14}$ Cases with vitreoretinal traction leading to macular hole and retinal detachment have also been reported. ${ }^{13}$

As per our knowledge, only one case of bilateral macular hole in XLRS with poor vision has been reported ${ }^{14}$ Our case was found to have good visual

\section{Learning points}

- X-linked retinoschisis (XLRS) can rarely manifest as a bilateral macular hole in young patients.

- Family history and multimodal imaging help in arriving at diagnosis of XLRS with macular hole in young patients. 
acuity of 20/100, N18 in spite of large holes and complete loss of photoreceptors and retinal pigment epithelium loss in the area of hole documented by OCT and FAF. This good visual acuity could be due to eccentric foveal fixation which has been reported in macular dystrophies. ${ }^{15}$

Contributors $D C P, P K R, A B$ - concept and design. DCP, AB — data collection. DCP, $P K R, A B$ - manuscript writing, editing and review.

Funding The authors have not declared a specific grant for this research from any funding agency in the public, commercial or not-for-profit sectors.

Competing interests None declared.

Patient consent for publication Obtained.

Provenance and peer review Not commissioned; externally peer reviewed.

ORCID iD

Padmaja Kumari Rani http://orcid.org/0000-0001-7069-8238

\section{REFERENCES}

1 Molday RS, Kellner U, Weber BHF. X-Linked juvenile retinoschisis: clinical diagnosis, genetic analysis, and molecular mechanisms. Prog Retin Eye Res 2012;31:195-212.

2 Staffieri SE, Rose L, Chang A, et al. Clinical and molecular characterization of females affected by X-linked retinoschisis. Clin Exp Ophthalmol 2015;43:643-7.

3 Kellner U, Brümmer S, Foerster MH, et al. X-Linked congenital retinoschisis. Graefes Arch Clin Exp Ophthalmol 1990;228:432-7.
4 Grayson C, Reid SN, Ellis JA, et al. Retinoschisin, the X-linked retinoschisis protein, is a secreted photoreceptor protein, and is expressed and released by WERI-Rb1 cells. Hum Mol Genet 2000;9:1873-9.

5 Molday LL, Hicks D, Sauer CG, et al. Expression of X-linked retinoschisis protein RS1 in photoreceptor and bipolar cells. Invest Ophthalmol Vis Sci 2001;42:816-25.

6 Sauer CG, Gehrig A, Warneke-Wittstock R, et al. Positional cloning of the gene associated with X-linked juvenile retinoschisis. Nat Genet 1997;17:164-70.

7 Apushkin MA, Fishman GA, Janowicz MJ. Correlation of optical coherence tomography findings with visual acuity and macular lesions in patients with X-linked retinoschisis. Ophthalmology 2005;112:495-501.

8 Renner AB, Kellner U, Fiebig B, et al. Erg variability in X-linked congenital retinoschisis patients with mutations in the RS1 gene and the diagnostic importance of fundus autofluorescence and OCT. Doc Ophthalmol 2008;116:97-109.

9 Khan NW, Jamison JA, Kemp JA, et al. Analysis of photoreceptor function and inner retinal activity in juvenile X-linked retinoschisis. Vision Res 2001;41:3931-42.

10 Brasil OFM, da Cunha ALG, de Castro MB, et al. Macular hole secondary to X-linked juvenile retinoschisis. Ophthalmic Surg Lasers Imaging 2011;42 Online:e4-5.

11 Shukla D, Naresh KB, Rajendran A, et al. Macular hole secondary to X-linked retinoschisis. Eye 2006;20:1459-61.

12 Al-Swaina N, Nowilaty SR. Macular hole in juvenile X-linked retinoschisis. Saudi J Ophthalmol 2013;27:283-6.

13 Shanmugam MP, Nagpal A. Foveal schisis as a cause of retinal detachment secondary to macular hole in juvenile X-linked retinoschisis. Retina 2005;25:373-5.

14 Gautam M, Muralidhar NS, Murthy H. Bilateral macular holes in X-linked retinoschisis: now the spectrum is wider. Indian J Ophthalmol 2011;59:507.

15 Chiang W-Y, Lee J-J, Chen Y-H, et al. Fixation behavior in macular dystrophy assessed by microperimetry. Graefes Arch Clin Exp Ophthalmol 2018;256:1403-10.

Copyright 2020 BMJ Publishing Group. All rights reserved. For permission to reuse any of this content visit

https://www.bmj.com/company/products-services/rights-and-licensing/permissions/

BMJ Case Report Fellows may re-use this article for personal use and teaching without any further permission.

Become a Fellow of BMJ Case Reports today and you can:

- Submit as many cases as you like

- Enjoy fast sympathetic peer review and rapid publication of accepted articles

- Access all the published articles

Re-use any of the published material for personal use and teaching without further permission

\section{Customer Service}

If you have any further queries about your subscription, please contact our customer services team on +44 (0) 2071111105 or via email at support@bmj.com.

Visit casereports.bmj.com for more articles like this and to become a Fellow 